\title{
DEVELOPMENT OF LOGIC AND ALGORITHM E-TRAINING MATERIAL WITH BLOCK PROGRAMMING
}

\author{
Prayitno ${ }^{1}$, Liliek Triyono ${ }^{2}$ \\ 1,2 Program Studi D3 Teknik Informatika, Politeknik Negeri Semarang, Kota Semarang, Jawa Tengah, Indonesia
}

\begin{abstract}
Integrating logical and analytical thinking activities to support 21 st century learning ability, into a learning activity at elementary and junior high school level becomes a challenge. One of them is less interesting learning media. One of the technologies that can be used to support exciting learning is block programming Alice and Scratch. This article aims to develop online training materials Logic and Algorithm utilize block programming scratch for level five elementary school and block programming Alice for level eight junior high school as eLearning content. The development of this research is carried out by Analysis-Design-Development-Implementation-Evaluation (ADDIE) development model. Initial products were reviewed and advised by 2 primary school teachers, 2 junior high school teachers. Product quality assessment is done based on content feasibility aspect, feasibility of presentation, language feasibility using Likert scale. The results data are then analyzed using the ideal scoring criteria to determine product quality. The results of the overall training content quality assessment show an average grade of 89.8 with good.
\end{abstract}

Index Terms—Block programming scratch, block programming Alice, eLearning content development, ADDIE.

\section{Introduction}

The 21st century learning is the ability to prepare learners facing global competition. There are four capabilities that must be owned by the 21 st century generation, namely: ways of thinking, ways of working, tools for working and living in the world in the article put forward by Rodger [1]. The 21st century learning ability goes hand in hand with the ministry of education regulation number 22 year 2016 (Content Standards) states the subjects of mathematics are given to all learners to equip them with logical, analytical, systematic, critical, and cooperative thinking abilities as disclosed by Shamsuar [2].

There are two things in Teaching and learning process in logical, analytical and systematic thinking (ways of thinking). First thing is a special material about thinking and material how to integrate the activities of thinking into a learning activity. Second, To integrate thinking activities into a learning activity at elementary and junior high schools (SMP) becomes a challenge in itself one of the less interesting learning media

By using computer technology, the learning process can be made interesting. Based on Rodger [3] and Gunawan [4] article one of technology to support exciting learning may be to use block programming Alice and Scratch application. Block programming makes it easy for users to create digital media such as storytelling and games to improve the learning of simple programming logic. Furthermore, block programming Scratch and Alice application can be utilized in the learning at grade level of elementary and junior high school at curriculum level 1 until 12 according to Cooper[5] Sykes[6] and Hansun[7].
This article discusses online training content training solutions and algorithms utilizing block programming Scratch app at the primary school level and block programming Alice application at the junior high school level.

\section{Related Work}

\subsection{Related Research}

Block programming is one program to help in introducing language and logic from an early age. The introduction of programming logic from an early age makes children more interested and enthusiastic to learn other disciplines such as science and math. So children can use logic and reasoning power well. Programming language is a technique for writing programs and giving commands on the computer in accordance with what we want. The programming language can facilitate communication between humans and machines. Programming languages can also be applied in the field of education. Educational programming language is made as a learning instrument, not as a tool for making real applications. Along with the development of technology, the need for introduction of programming language from an early age.

Gunawan [4] in his research used visual programming scratch applications to support the introduction of computer programming for TPQ teachers. The teachers are equipped with the ability to create learning media using scratch applications. Based on the results of the study 60 percent of respondents stated that visual programming is easy to use to create learning media, although the previous user does 
not have the ability to recognize the programming language and application creation.

In another study, Toheri[8] used visual block programming to help learners improve creativity of mathematical thinking. The use of visual programming has a positive effect on the creativity of mathematical thinking with the magnitude of influence of 12.4 percent. The study shows good visual programming to be used in order to enhance creative learning.

\subsection{Technology Research}

\subsubsection{Block Programming Scratch}

Scratch is an open source application that is a computer program that can be used for free without having to pay the license. The advantages of open source gives freedom in the use and development of the program. The program was developed by Kindergarten Group at MIT Media Lab, with financial support from the National Science Foundation, Microsoft, Intel Foundation, MacArthur Foundation, Google, Iomega and MIT Media Lab research consortium. This program can be downloaded at http://scratch.mit.edu/.

Scratch displays a very simple and easy to use interface. The concept of scratch programming is visualized in the form of program blocks such as installing a puzzle. Scratch can be used to create applications, animations, and games. The cat image in Figure 1 is a sprite as well as the logo of this application program.

\begin{tabular}{|l|l|}
\hline Sample code in Java and Python & Sample of block code programming in Scratch \\
Print ("Hello World") & System.out.println("Hello World") \\
& Block Code Program \\
\hline
\end{tabular}

Fig 1. Text and Block Programming

There are several reasons why we choose Scratch as a medium of introduction to programming logic at an early age, that is because Scratch has the following advantages:

- Scratch has a small size compared to other programming languages.

- The interface is very simple and easy to use for children.

- Children are easier to learn programming logic without having to be complicated by writing syntax in common programming languages.

- Scratch helps kids create interactive stories, animations and games.

- Scratch allows everyone to easily combine images, sound and video without having the special ability in the field of programming.

- Animations can be formed, executed and controlled.

- Scratch is capable of running on Windows, Linux or Macintosh operating systems.
Make a program with the Scratch, as easy as the kids are building blocks of toys-sort of Lego-to build toy houses or toy cars. Scratch can provide blocks that can be arranged easily, then given commands such as: walking, sleeping, playing flute, and the like. Because of its ease, Scratch is intended for children, so if during this time learner just play games with computers, they also now can make their own games. This is an excellent way to channel the creativity of learners and can provide them with the opportunity to learn and play (edutainment).

\subsubsection{Block Programming Alice}

Alice is not an OOP language, Alice "object-based", not "object-oriented". Alice is a visual programming environment for defining objects and managing interactions between objects generating animation programs. Alice is not used to learn real OOP / depth, but gives a sense of the object and interaction between objects.

In general, Alice is an innovative $3 \mathrm{D}$ programming environment that makes it easy to create animations to tell stories, play interactive games, or share videos on the web. Alice is a free teaching tool available designed to be the first exposure of students to object-oriented programming. This allows students to learn the basic concepts of programming in order to create simple animated movies and video games. In Alice, 3D objects (eg, humans, animals, and vehicles) fill cyberspace and students create programs to animate objects.

Alice can also be interpreted as an object-based programming language freeware education programming with an integrated development environment (IDE). Alice uses drag and dropping environments to create computer animations using 3D models. The software was developed first at the University of Virginia, then Carnegie Mellon (from 1997), by a research group led by the late Randy Pausch. Alice can be downloaded at http://www.alice.org/.

Alice was developed to help the learning process because it has advantages:

- Alice is designed solely to teach programming theory without the complex semantics of production languages like $\mathrm{C}++$.

- Users can place objects from Alice's gallery into the virtual world they imagine, and then they can program by dragging and dropping tiles that represent the logical structure. In addition, users can manipulate Alice's camera and lighting to make further enhancements. Alice can be used for 3D user interface.

- Alice is simulated with an integrated editor.

There is no syntax to remember. However, it supports full object-based programming, event driven programming model.

- Alice is designed to attract certain subpopulations normally not exposed to computer programming, such as high school age students, by encouraging storytelling. Alice is also used in many colleges and universities in Introduction to Programming courses.

- In a controlled study at Ithaca College and Saint Joseph University saw students without prior 
programming experience taking their first computer science course, the average grade increased from $\mathrm{C}$ to $\mathrm{B}$, and retention increased from $47 \%$ to $88 \%$.

- Alice is released under an open-source license that allows redistribution of source code, with or without modification, for non-commercial use only.

\section{Proposed Method}

Research content development training online logic and algorithms utilize Block Programming done for 4 months. Furthermore, the development is done in State Polytechnic of Semarang and the place of research is done in SD Pedurungan Tengah 02 and SMP Negeri 33 Semarang. In this study take the subject of logic and algorithm material on computer learning. The object of this research is the quality of training content of online logic and algorithms utilizing block programming in terms of content feasibility aspects, feasibility of presentation, language feasibility and visual communication.

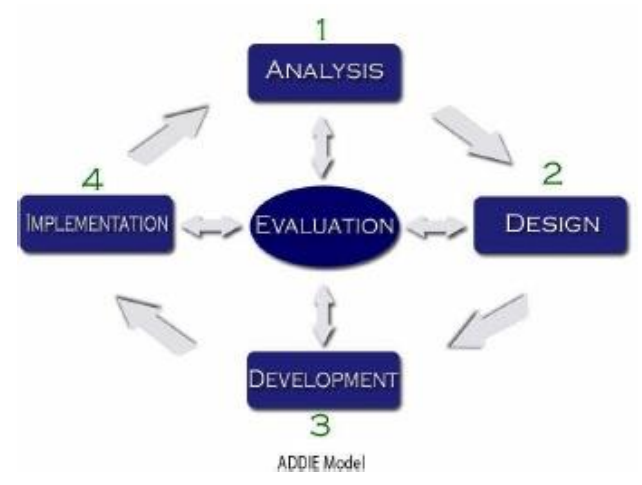

Fig 2. ADDIE Elearning Content Development Method

The procedure for developing the online training materials using the ADDIE development model consists of five stages, but is limited to the fourth stage of implementation which is divided into the following stages:

\subsection{Analysis}

In the first stage determine the benefits and objectives of training content content online logic and algorithms utilize block programming scratch and alice. Furthermore, a review of the indicator must be done in the syllabus. The next stage in the analysis phase is a reference search in the form of books, journals, articles related to research.

\subsection{Design}

The preparation and validation of the materials to be included in the content of online training. Making presentation and video material used in online training. Establishment of teacher response instruments and training participants on training content.

\subsection{Development}

At the development stage, some activities such as validation of the material quality assessment instrument on peer assessment and participants, the making of video material using computer recorder software into Camtasia and Snagit video, Making presentation material and training module in the form of power point and pdf. Then upload the learning content to the http://mooc.seamolec.org/ online training site as well as the initial product revision after peer review and enter by online training participants.

\subsection{Implementation}

Implementation steps include the assessment of the quality of instructional content by small groups of elementary and junior high school teachers. Data analysis obtained is used to determine product quality. Then, final material refinement based on input from participants and teachers.

\section{Product and Data Type Evaluation}

Initial assessment of draft material examined by peer review of elementary teachers for block programming scratch and block programming alice for SMP. The product of online training materials is then refined and tested with online participants at the elearning website http://mooc.seamolec.org/.

Data obtained in this development include product development process data in accordance with established development procedures, product development process data from online training materials based on input from learning experts, media experts and four reviewers and data on product quality viewed from four teachers as reviewers and learners.

\section{Result and Discussion}

The result of this development research is in the form of online training module in the form of text, image and video of logic material and algorithm utilizing block programming scratch for teachers at elementary level and block programming alice for teachers at junior high school level. Training materials include training modules, training evaluations and certificates after training.

Acquisition of data based on product development result includes material development process data, quality research data by reviewer and teacher training quality data quality. The data of training module material development process is obtained from material experts, IT experts and peer review in the form of corrections, suggestions and inputs used to develop and revise the training module material. Quality research data by reviewers and teachers is data the quality obtained based on reviewer and teacher judgments based on assessment instruments. The material 
quality data of the training module aims to determine the level of eligibility during the training process.

The quality of training module data from reviewers by using questionnaire contains the ideal scoring criteria developed into 4 aspects covering materials and exercises, language used, implementation, audio and visual display. Aspects of product quality assessment are described more specifically in 13 indicators. The results of the overall training content quality assessment show the average score of 89.8 can be seen in table 1. Done with small group consisting of 5 reviewers.

Table 1. The quality of the Training Material as a whole based on reviewers' judgment

\begin{tabular}{llllll}
\hline Reviewer & I & II & III & IV & V \\
\hline Score & 58 & 58 & 59 & 57 & 60 \\
Total & 292 & & & & \\
Average Score & 58.4 & & & \\
Score Range & $\bar{X}>54.48$ & & & \\
Quality Category & Very Good & & \\
Percentage & $89.8 \%$ & & & \\
\hline
\end{tabular}

Product assessment of instructional content based on every aspect is also done in order to know product quality more specifically. In summary, the quality of content learning products can be seen in table 2 .

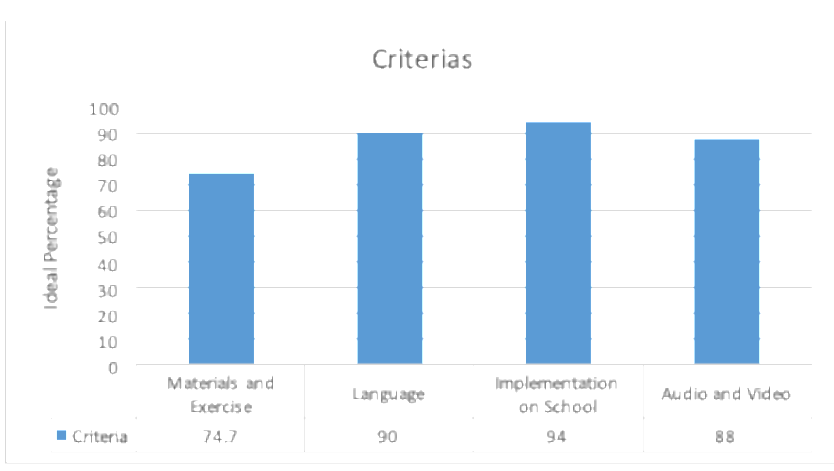

Fig 3. Reviewers ratings chart

Material and exercise aspects have the lowest percentage of other aspect of $74.7 \%$ so that enter in good quality category. One assessment from the reviewer because it is considered the exercises are still in the technical field and a little touching the realm of support material support.

Two other aspects of linguistic aspects and aspects of audio and video display respectively are in the category of excellent quality with the percentage of $90 \%$ and $88 \%$. Based on reviewers' ratings on audio and visual display aspects it can be concluded that the audio and visual display is very good because of the use of color, music, and clarity of illustration.

Table 2. Quality of each aspect from elearning material

\begin{tabular}{|c|c|c|c|c|c|}
\hline Criteria & $\begin{array}{l}\text { Indicator } \\
\text { Number }\end{array}$ & Average Score & $\begin{array}{l}\text { Maximum } \\
\text { Score }\end{array}$ & Quality Category & $\begin{array}{l}\text { Ideal } \\
\text { Percentage }\end{array}$ \\
\hline Materials and Exercise & 5 & 22.4 & 30 & $\begin{array}{l}\text { Good } \\
\qquad 20.4<\bar{X} \leq\end{array}$ & $74.7 \%$ \\
\hline Language & 2 & 9 & 10 & $\begin{array}{l}\text { Very Good } \\
\qquad \bar{X}>8.4\end{array}$ & $90 \%$ \\
\hline Implementation on School & 2 & 9.4 & 10 & $\begin{array}{l}\text { Very Good } \\
\qquad \bar{X}>8.4\end{array}$ & $94 \%$ \\
\hline Audio and Video & 4 & 17.6 & 20 & $\begin{array}{l}\text { Very Good } \\
\qquad \bar{X}>8.4\end{array}$ & $88 \%$ \\
\hline
\end{tabular}

Based on the graph of percentage in figure 3, it can be concluded that the aspect of implementation has the highest percentage of $94 \%$ so it is included in the criteria is very good. Reviewers judge very well because schools can facilitate the equipment and development of teacher resources in implementing improved learning materials through these training materials.

\section{Conclussion}

In this research article, ADDIE method can be used to develop online training materials of logic and algorithm utilize block programming scratch. This training material can be done at the 5th grade primary school level on theme material 1 multiplier and level 8 junior high school on mathematics sub sub numbers. Furthermore, the quality and appropriateness of logic learning materials and algorithms using block programming is measured through 4 aspects of the material and exercises, the language of the implementation and the visual appearance of the audio visual eLearning is good. 


\section{Acknowledgement}

My acknowledgement is given to Southeast Asian Minister of Education Organization Open Learning Center (SEAMOLEC), who has provided me with research grant, in making this research and presentation possible. Financial support from SEAMOLEC has helped many Indonesian researchers in open and distance learning.

\section{References}

[1] S. H. Rodger et al., "Enhancing K-12 education with alice programming adventures," Proc. fifteenth Annu. Conf. Innov. Technol. Comput. Sci. Educ. - ITiCSE '10, p. 234, 2010.

[2] N. R. Shamsuar, "Game Design as a Tool to Promote Higher Order Thinking Skills," Int. J. Innov. Educ. Res., vol. 2, no. 6, pp. 51-58, 2014.

[3] Lifelong Kindergarten Group, "Getting Started With Scratch Version 2.0," M.I.T. Media Lab, 2013.

[4] D. Gunawan, F. Yasin, and A. Irsyadi, "Pemanfaatan Pemrograman Visual Sebagai Sarana Pengenalan Pemrograman Komputer Untuk Pembuatan Game Edukasi," vol. 15, no. 2.

[5] S. Cooper, W. Dann, and R. Pausch, "Alice: a 3-D tool for introductory programming concepts," J. Comput. Sci. Coll., vol. 15, no. May 2000, pp. 107-116, 2000.

[6] E. Sykes, "Determining the Effectiveness of the 3D Alice Programming Environment at the Computer Science I Level," $J$. Educ. Comput. Res., vol. 36, no. 2, pp. 223-244, 2007.

[7] Hansun, "Pemrograman Visual untuk Semuanya," J. Ultim. InfoSys, vol. V, no. 1, pp. 41-48, 2014.

[8] Toheri and Nuraenafisah, "PENGARUH PENGGUNAAN SCRATCH TERHADAP KREATIVITAS BERFIKIR MATEMATIS (Studi Eksperimen Terhadap Siswa Kelas VIII MTs Negeri

Ketanggungan Kabupaten Brebes)," Eduma, vol. 2, no. 1, 2013. 